\title{
Effectiveness of Project Based Learning (PjBL) to Improve Natural Science Learning Outcomes Of Grade IV Students
}

\author{
Turyati, Sri Hartati, Nursiwi Nugraheni \\ Elementary of Teacher Education Majors, Faculty of Education, Universitas Negeri Semarang \\ Corresponding email: turyati05pgsd@gmail.com
}

\begin{abstract}
This research aimed to determine the effectiveness of Project Based Learning (PjBL) with the model in control class towards science learning outcomes on Elementary School fourth grade students in Cluster Ikan Lodan Semarang. The research is a quasi-experimental design with pretest posttest nonequivalen control group design. The population is all students of SDN in Cluster Ikan Lodan. Sampling technique is purposive sampling. The Data collection techniques are observation, testing and documentation. The results showed that $t_{\text {hitung }}>\mathrm{t} \mathrm{table}_{\mathrm{a}}$ is 3,22>2,00 it means ho rejected and ha accepted. The conclusions of this study is the experimental class that implements the Project Based Learning (PjBL) model is more effective than applying the model on class control with Contextual Teaching and Learning (CTL) on material changes the physical environment in the fourth grade students of SDN in cluster Ikan Lodan North Semarang districts.
\end{abstract}

Keywords: science teaching quality; effectiveness; project based learning

\section{Introduction}

Under Peraturan Menteri Pendidikan Nasional Nomor 22 Tahun 2006 (Regulation of Minister of Education:22/2006), it was stated that Natural Science (IPA) is related to the ways to find out about the nature systematically thus natural science is not only concerning the mastery of a series of knowledge in form of facts, concepts, or principles, but also regarding the invention process. The Natural Science teaching is expected to become a mode for the students to learn about themselves and their environment, as well as the prospectus of further development in terms of daily application. Its learning process puts emphasis on the direct experience to develop their competencies to explore and to understand their surroundings scientifically.

Some international institutions reported that the Indonesia has slow development on education field. This was shown in the research conducted by PISA (the Programme for International Student Assessment) published in 2012 themed" Evaluating School System to Improve Education" attended by 34 member countries OECD (Organization for Economic Cooperation and Development) and 31 partner countries (including Indonesia) representing over $80 \%$ world economies. It involved about 510.000 students from 65 participating countries, shows that the Indonesian students' mathematics, science, and reading skills are still poor compared the other students from the other countries.

I also found a problem in the Natural Science learning on grade IV students of SDN
Gugus Lodan, District of Semarang Utara. Based on the observation that I made on grade IV students of a public primary school in District of Semarang Utara, the teacher had not applied the innovative learning method. The Natural Science learning was still teachercentered. The students were less involved in terms of discovering the knowledge by themselves. The teacher still used the textbook excessively and used less other learning resources. The applied teaching tools were less innovative. That made the learning process monotonous, the students were less involved in critical thinking, thus the learning outcomes became poor and far from the target that would like to be achieved.

From the problems described above, one of the causes of the students' poor understanding of the concepts in Natural Science are that the learning method that the teacher applied was not innovative. Among the innovative learning methods are Project Based Learning (PjBL) dan Contextual Teaching and Learning (CTL).

PjBL can improve the problem-solving skill to the complex problem by involving the students to make observations, to hold discussion, and to create some works to clarify the lesson materials. While, CTL method cannot. PjBL also gives the students the real experiences regarding the practices of organizing the projects, allocating time and the other resources such as the tools and equipment to accomplish the tasks. While in CTL, the students do not make the project organization like what they do in the project-based learning. 
The learning applying PjBL also will improve the students learning motivation. It can be viewed when the students try hard to complete the project. In addition, $\mathrm{PjBL}$ will create the enjoyable learning atmosphere because the carried-out projects are challenging which is not found in the learning of the other subjects, therefore the students will be active and enjoy the learning process. (Daryanto,2014:25)

Based on the explanation above, is Project Based Learning (PjBL) more effective compared to the learning method applied to the control classroom of the Natural Science learning for grade IV students of public schools in Gugus Ikan Lodan District of Semarang Utara Semarang City?

While this study aims to find out the effectiveness of Project Based Learning (PjBL) compared to control classroom on grade IV students Natural Science learning outcomes in public schools in Gugus Ikan Lodan Semarang City.

\section{Research Methods}

The study used quasi experimental method. The research design used in this study was pretest-posttest nonequivalent control group Design. The research procedure consists of two stages, i.e. pre-research (permission asking the concerning primary school, observation, initial data collection, determining the experimental and control and trial group, composing the questions as instruments, conducting the instrumental testing, and writing lesson plan). The research stage comprises pretest, analyzing the pretest results, undertaking the learning based on the lesson plan for 6 lessons, conducting posttest. Subject of this study was grade IV students of public schools in Gugus Ikan Lodan District of Semarang Utara Semarang City comprising SDN Dadapsari, SDN Purwosari 01, SDN Purwosari 02, SDN Kuningan 02, and SDN Kuningan 04. This investigation was conducted during even semester of 2015/2106 school year. Population to this study was grade IV students of public schools in Gugus Ikan Lodan District of Semarang Utara Semarang City.

This study took two classrooms as samples. One classroom was used as experimental classroom and I used another one as the control one. The experimental one was grade IV of SDN Purwosari 02 and the control one was grade IV SDN Kuningan 04. I also picked one more classroom as the trial one, i.e. grade IVB SDN Purwosari 01, other than the previous two. The sampling method that I used was purposive sampling, i.e. the sampling method based on the certain consideration. The data were collected through observation, testing, and documentation. I used essay questions as the instruments. The data subsequently would be analyzed by validity, reliability, degree of difficulty, and discrimination index assessment. The data analyses used in this study were normality, homogeneity, and equality of variances tests.

\section{Results And Discussion}

The study was conducted in six lessons in experimental and control classrooms. Before the learning started, the students did pretest to find out their initial readiness and ability.

Table 1. Final Data for Pretest conducted in Experimental and Control Classroom

\begin{tabular}{llll}
\hline $\begin{array}{l}\text { Classro Numbe Averag HighestLowest } \\
\text { om }\end{array}$ & $\begin{array}{c}\text { of } \\
\text { icore }\end{array}$ & icore \\
\multicolumn{2}{c}{ itudents } & & \\
\hline Experi 33 & 60.39 & 95 & 41 \\
nental 37 & 60.4 & 86 & 43 \\
Control & & & \\
\hline
\end{tabular}

Subsequently, the learning then was applied into six lessons. Then I conducted posttest to find out the Natural Science learning outcomes. The followings are the final data for posttest conducted in the two classrooms.

Table 2. Final Data for Posttest Conducted in Experimental \& Control Classrooms

\begin{tabular}{lllll}
\hline $\begin{array}{l}\text { Classro } \\
\text { om }\end{array}$ & $\begin{array}{l}\text { Number AverageHighest Lowest } \\
\text { of } \\
\text { Student }\end{array}$ & Score & Score \\
& $\begin{array}{llll}\text { Stude } \\
\text { S }\end{array}$ & & & \\
\hline Experi & 33 & 78.81 & 100 & 60 \\
mental & 37 & 72.24 & 95 & 60 \\
Control & & & \\
\hline
\end{tabular}

Then the posttest scores were analyzed by normality test to find out if the data were distributed normally or were not. The followings are the results of normality test in both experimental and control classrooms. 
Table 3. Normality Test for Posttest Conducted in Experimental \& Control Classrooms

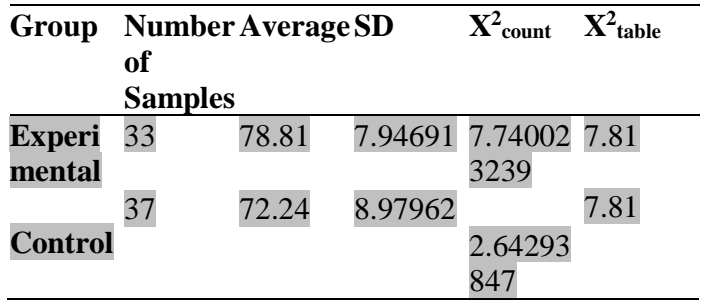

Table 4. Homogeneity Test of Posttest Conducted in Experimental \& Control Classrooms

\begin{tabular}{lllll}
\hline Group Sample & $\mathbf{S}^{\mathbf{2}}$ & $\mathbf{F}_{\text {count }}$ & F $_{\text {table }}$ \\
\hline $\begin{array}{l}\text { Experime33 } \\
\text { ntal }\end{array}$ & 168.8087 & \\
& \multicolumn{2}{c}{1.75} & 1.78 \\
Control & 37 & 96.30781 & \\
\hline
\end{tabular}

Based on the table 4, I found that $\mathrm{F}_{\text {count }}<$ Ftable i.e. $1.27<1.76$. This means that the proposed hypothesis null (Ho) was accepted and Ha was rejected at level of significance $5 \% \mathrm{dk}$ quantifier $=(\mathrm{n}-1)$, and $\mathrm{dk}$ denominator $=(\mathrm{n}-1)$. Thus I can make a conclusion that the two sample groups came from the similar population.

The followings are the results of hypothesis tests comparing posttests in experimental and control classrooms.

Table 5. T-test of Posttest for Experimental and Control Classrooms

\begin{tabular}{lll}
\hline Remarks & $\begin{array}{l}\text { Experimental } \\
\text { Classroom }\end{array}$ & $\begin{array}{l}\text { Control } \\
\text { Classroom }\end{array}$ \\
\hline Sample & 33 & 37 \\
Average & 78.81 & 72.24 \\
$\mathbf{S}^{\mathbf{2}}$ & 63.135 & 80.633 \\
$\mathbf{T}$ count & & \\
$\mathbf{T}$ table \\
conclusion & & \\
& 3.22 & \\
& 2.00 \\
& Ho was rejected, \\
& Ha was accepted \\
\hline
\end{tabular}

From table $5 \mathrm{I}$ can conclude that $\mathrm{t}_{\text {count }}>$ ttable this means that Ho was rejected and $\mathrm{Ha}$ was accepted. With the proposed hypothesis that if $t_{\text {count }}<t_{\text {table }}$ at level of significance $5 \%$ then Ho was accepted and $\mathrm{Ha}$ was rejected and if $t_{\text {count }}>$ ttable then Ho was rejected and Ha was accepted at level of validity (n2+n1)-2. I can conclude that "the average Natural Science learning outcomes of grade IV students of public primary schools in Gugus Ikan Lodan has significant difference".

The thing that support the opinion that Project Based Learning ( $\mathrm{PjBL}$ ) is better than Contextual Teaching Learning (CTL) is that $\mathrm{PjBL}$ made the students more enthusiast in terms of finishing the project of diorama that will visualize the lesson materials. The lesson material investigated in this study was the mutation of physical environment. PjBL suited the lesson material because it was in line with the reality of real world and was started with deep investigation. This is in line with the statement of (Daryanto, 2014: 26) that PjBL involves the students in learning to collect information and to show the knowledge they have, and then to actualize. In addition, PjBL makes the students more active and able to solve the complex problems through discussion, improve the students' skill to manage the learning resources by observation, investigation, and experiment. It could also improve the learning motivation as well as push their capability of doing the important and organized works.

Another thing supporting PjBL to be more effective was the usage of the concrete teaching tool adjusted to the students' development. Piaget revealed that primaryschool students' development was in the concrete operational stage, thus to teach something a teacher must use the concrete things. The usage of concrete medium and teaching tool will make the taught concept clearer and will improve the students' understanding about the concept. This is similar to what was revealed by Edgar Dile, i.e. the more concrete the teaching tool that is used, the better knowledge the students will get.

It was also supported by my field note during the learning, the students of the experimental classroom looked enthusiast when doing the investigation and the experiment. The students were easily and orderly conditioned when being divided into several learning groups. The students used the teaching tool skillfully. The learning atmosphere felt good because they were involved in the works creation in form of diorama. The competitiveness appeared when they competed to create the best diorama. The self-confidence of each group was also high, it was observable when they undoubtedly went forward to present their works. That was not viewable in the 
control classroom, the students were less enthusiast, and less manageable during the group creation. The average evaluation and project score of the classroom applying $\mathrm{PjBL}$ was 75.11 and 76.41. While the average evaluation and project score of the classroom applying CTL was 73.3 and 54.31. The teacher who taught the experimental classroom was also more skilled and understood syntax better, while the one teaching the control classroom was less skilled and understood the syntax less. It was shown by the average score after observing teachers' skill of every lesson, i.e. $82.61 \%$ in experimental classroom and $74.62 \%$ in control classroom. In addition, the average score for the students' activities for each lesson in experimental classroom was $80.53 \%$, and the one in control classroom was $70.34 \%$. The research result was supported by another study conducted by another scholar, such as:

The investigation conducted by $\mathrm{Ni}$ Ketut Suarni, Nyoman Dantes, and I Nyoman Tika titled "Pengaruh Model Pembelajaran Berbasis Proyek Terhadap Minat dan Hasil Belajar IPA Kelas V SDN Gugus 1 Kecamatan Kuta" (Impact of Project-Based Learning on Interest in and Learning Outcomes of Natural Science of Grade IV Students of SDN Gugus 1, District of Kuta) (2014). The study shows that the Natural Science learning outcomes as dependent variable has F-value 12.909 at level of significance 0.001 or less than 0.05 . This shows that F-value of Natural Science learning outcomes as dependent variable was significant.

The research conducted by Indah Susilowati, Retno Sri Iswari, and Sri Sukaesih titled "Pengaruh Pembelajaran Berbasis Proyek Terhadap Hasil Belajar Siswa Materi Sistem pencernaan Manusia" (The Impact of ProjectBased Learning on the Students Learning Outcome of Human Digestion System Lesson) (2014). The average difference assessment of posttest score shows that the average posttest score for experimental classroom was better than the one for the control classroom ( $t_{\text {count }}>$ ttable). In addition, the average students' final score in experimental classroom was higher than control classroom.

Another investigation conducted by Ratna Danarti titled "Perbedaan Hasil Belajar IPS Model Project-Based Learning Berbasis Outdoor Study dengan Konvensional Siswa SMP" (The Difference of Social Science Learning Outcomes between Outdoor Study-
Based Project-Based Learning and Conventional Learning of Secondary-School Students) (2014). The study shows that Outdoor-Study-based Project-Based Learning could work excellently in accordance with its syntaxes and the students' responses showed the good result, too.

The study conducted by Dewi Astuti, Wagiran, and Septina Sulistyaningrum titled "Keefektifan Model Pembelajaran Berbasis Proyek Dalam Meningkatkan Kompetensi Menyusun Teks Cerita Prosedur Peserta Didik Kelas VIII" (The Effectiveness of Project-Based Learning in terms of Improving the Grade VIII Students' Competencies of Writing Procedure Text) published in 2015. The study shows that project-based learning was effective to improve behavioral competencies such as independence, the cognitive one, and the skill one in terms of writing procedure text of grade VIII students.

The investigation conducted by Ida Ayu Kade Sastrika, I Wayan Sadia, and I Wayan Muderawan titled "Pengaruh Model Pembelajaran Berbasis Proyek Terhadap Pemahaman Konsep Kimia Dan Keterampilan Berpikir Kritis" (The Impact of Project-Based Learning on the Understanding of Chemistry Concepts and Critical-Thinking Skill) (2013). The study (1) shows that there was difference of concept understanding and critical-thinking skill between the students following the projectbased learning and those following conventional learning $(\mathrm{F}$-count $=13.921>\mathrm{F}$-table $=3.91$.

The research made by Yilmaz Cakici dan Nihal Turkmen titled "An Investigation of the Effect of Project-Based Learning Approach on Children's Achievement and Attitude in Science" (2013). The study shows that the students' achievement on the knowledge improved significantly by project-based learning, their responses, however, to the knowledge remained

The research conducted by Karina, Sadia, Suastra titled "Pengaruh Pembelajaran Berbasis Proyek Terhadap Kemampuan Pemecahan Masalah dan Kecerdasan Emosional Siswa SMP" (The Impact of ProjectBased Learning on Secondary-School Students' Problem-Solving Skill and Emotional Quotient) (2014). The study shows that: (1) the learning method has significant impact on problemsolving skill and emotional quotient as variables $(\mathrm{F}=41.134 ; \mathrm{p}<0.05,(2)$ the students applying the project-based learning has significantly different problem-solving skill from the ones 
applying conventional learning $(\mathrm{F}=75.638 ; \mathrm{p}<$ $0.05)$.

The research conducted by Eskrootchi Rogheyeh, and Oskrochi G. Reza (2010) titled "A Study of the Efficacy of Project-based Learning Integrated with Computer-Based Simulation-STELLA". The study shows that the students learnt well and actively built their knowledge from the combination of experience, interpretation, and structured interaction with their peers when applying simulation in $\mathrm{PjBL}$ setting.

The investigation of Salam Faridah, Mailok Ramlah, Ubaidullah Norhasbiah and Ahmad Umar (2016) titled "The Effect of Project-Based Learning Against Students' Engagement". The study shows that there was significant difference in terms of the students' engagement. This finding shows that the application of project-based learning is effective to promote the students learning in order to improve their engagement.

\section{Conclusion}

The average Natural Science learning outcome in the classroom where Project Based Learning (PjBL) was applied was better than the learning in the control classroom where Contextual Teaching Learning (CTL) was applied to grade IV students in the lesson of physical environmental change. Thus, I can conclude that Project Based Learning is effective to be applied to the Natural Science leaning for grade IV students of public primary schools in Gugus Lodan District of Semarang Utara Semarang City.

\section{References}

Abidin,Yunus.2016. Desain Sistem Pembelajaran dalam Kurikulum 2013. Bandung:PT Refika Aditama.

Astuti Dewi, Wagiran, dan Septina Sulistyaningrum. 2015. Keefektifan Model Pembelajaran Berbasis Proyek Dalam Meningkatkan Kompetensi Menyusun Teks Cerita Prosedur Peserta Didik Kelas VIII. Vol 4 hal 1-8. Journal Pendidikan Bahasa dan Sastra Indonesia . http://journal.unnes.ac.id/sju/indeks.php.j pbsi
Cakici Yilmaz dan Turkmen Nihal. 2013. An Investigation of the Effect of ProjectBased Learning Approach on Children's Achievement and Attitude in Science. Vol 4 issue 2 hal 9-17. TOJSAT. www.tojsat.net

Cresswel. John W. 2013. Research Design. Yogyakarta. Pustaka Pelajar

Danarti Ratna. 2014. Perbedaan Hasil Belajar IPS Model Project-Based Learning Berbasis Outdoor Study dengan Konvensional Siswa SMP. Vol 2 no 2 hal. Hal102-111. Jurnal Penelitian Humaniora.

http;//journal.um.ac.id/indeks.php/jph

Daryanto. 2014. Pendekatan Pembelajaran

Saintifik Kurikulum 2013. Yogyakarta. Gava Media.

Depdiknas. 2006. Standar Isi. Jakarta: Dirjen Depdiknas.

Eskrootchi Rogheyeh, dan Oskrochi G. Reza . (2010). A Study of the Efficacy of Projectbased Learning Integrated with Computerbased Simulation STELLA. Educational Technology \& Society, 13 (1), 236-

245.http://www.ifets.info/journals/13_1/2 2.pdf

Karina D.K.N, Sadia W I, Suastra WI. 2014. “ Pengaruh Model Pembelajaran Berbasis Proyek Terhadap Kemampuan Pemecahan Masalah dan Kecerdasan emosional Siswa SMP." Vol 4. Hal 1-10. Ejournal Undikhsa.

Koparan Timur, Guven Bulent . 2012. The Effect on the 8th Grade Students' Attitude towards Statistics of Project Based Learning. Vol 3 no 2. Hal 73-85. European Journal Of Education Research. http://www.eurojedu.com

Salam Faridah , Mailok Ramlah, Ubaidullah Norhasbiah dan Ahmad Umar. (2016). The Effect Of Project-Based Learning Against Students' Engagement. International Journal of Development Research. ol. 6, Issue, 02, pp. 6891-6895. http://www.journalijdr.com/sites/default/f iles/4861.pdf 
Sastrika Ida Ayu Kade, Sadia I Wayan, dan I Wayan Muderawan yang berjudul. 2013. Pengaruh Model Pembelajaran Berbasis Proyek Terhadap Pemahaman Konsep Kimia Dan Keterampilan Berpikir Kritis. Vol 3. E-journal Program Pascasarjana Universitas Pendidikan Ganesha.

Slavin, Robert. E. 1994. Educational Psychology; Theory and Practice. USA. Paramount Publishing.

Suarni Ni Ketut, Dantes Nyoman dan I Nyoman Tika. 2014. Pengaruh Pembelajaran Berbasis Proyek Terhadap Minat dan Hasil Belajar IPA Siswa Kelas V SD Gugus 1 Kecamatan Kuta. Vol 4 .E journal Program Pasca Sarjana Universitas Pendidikan Ganesha.

Sudjana. 2005. Metoda Statistika. Bandung. Tarsito

Sugiyono. 2014. Metode Penelitian Pendidikan Pendekatan Kuantitatif, Kualitatif, dan $R \& D$. Bandung. Alfabeta.

Susilowati Indah, Iswari Retno Sri, dan Sri Sukaesih. 2013. Pengaruh Pembelajaran Berbasis Proyek Terhadap Hasil Belajar Siswa Materi Sistem pencernaan Manusia. Vol 2 no 1. Hal 83-90. Unnes Journal of Biology Education. http//journal.unnes.ac.id/sju/indeks.php/uj $\mathrm{eb}$ 